www.nature.com/hr

\title{
COMMENTARY
}

\section{Does subclinical thyroid dysfunction affect blood pressure?}

\author{
Yukiko Nakata \\ Hypertension Research (2011) 34, 1071-1072; doi:10.1038/hr.2011.124; published online 4 August 2011
}

\begin{abstract}
$\mathrm{A}^{\mathrm{h}}$ highly sensitive immunoassay for thyroid-stimulating hormone (TSH) was developed in the 1980's for the diagnosis of patients with subclinical thyroid dysfunctions. The frequency of subclinical hypothyroidism is $4.3-11.8 \%$ and that of subclinical hyperthyroidism is $0.7-1.5 \%{ }^{1}$ An association between subclinical hypothyroidism and cardiovascular risks and the development of atherosclerosis has been reported. ${ }^{2}$ Subclinical hyperthyroidism reportedly increases heart rate, the frequency of arrhythmia (including atrial fibrillation), left ventricular mass and the risk of cardiovascular mortality; it also impairs ventricular relaxation. ${ }^{3}$ However, the relationship between subclinical thyroid dysfunction and hypertension has remained controversial.

In this issue, Cai et al. ${ }^{4}$ report the result of a meta-analysis, in which they aimed to determine whether subclinical thyroid dysfunction affects blood pressure. Their findings indicate that subclinical hypothyroidism is associated with a significant risk of increased blood pressure, both systolic and diastolic blood pressure, whereas subclinical hyperthyroidism is not associated with increased blood pressure. ${ }^{4}$ They suggest that the controversy regarding the relationship between subclinical hypothyroidism and hypertension may derive from the small number of subjects in the case-control studies, selection bias, or differences in race, lifestyle and genetic background among the sampled population. ${ }^{4}$ We need to consider several aspects of thyroidology and laboratory medicine as factors that affected the analysis of the results. These aspects can be divided into the following four concepts.
\end{abstract}

Correspondence: $\operatorname{Dr} Y$ Nakata is at the Department of Laboratory Medicine, Osaka University Graduate School of Medicine, Osaka, Japan.

E-mail: ynakata@labo.med.osaka-u.ac.jp
First, the Japanese Thyroid Association showed that approximately $30 \%$ of patients in Japan with subclinical hypothyroidism were positive for the antithyroid antibody and were diagnosed as having chronic thyroiditis. Iodine is a requisite substrate for the synthesis of thyroid hormones, and a daily intake of $150 \mu \mathrm{g}$ of iodine is recommended. Environmental iodine deficiency continues to be a significant public health problem worldwide $^{5,6}$ Iodine deficiency has serious effects on the physical development of children, on mortality among children and on the reproductive performance of women with increased rates of miscarriage, stillbirth and congenital abnormalities. Intellectual development is impaired, and in severe cases mental defects ranging up to cretinism may result. The World Health Organization (WHO) recommends salt iodization to prevent iodine deficiency. ${ }^{6}$ According to the WHO Global Database, which presents data from $92.1 \%$ of the world's population of 6 - to 12 -year-olds (school-age children), iodine deficiency is a public health problem in 54 countries. The iodine intake of a total of $36.5 \%$ (285 million) school-aged children in the world was estimated to be insufficient. The highest proportions of iodine-deficient children are found in Europe (59.9\%), whereas the lowest are found in the Americans $(10.1 \%)$. On the other hand, iodine intake was more than adequate or even excessive in 29 countries. ${ }^{5}$ Japanese individuals usually ingest more than $1.2 \mathrm{mg}$ of iodine daily, because more sea weed, a major source of dietary iodine, is consumed in Japan than in western countries. ${ }^{7}$ Because the quantity of iodine intake varies greatly among races and countries, it is difficult to eliminate the influence of iodine intake on thyroid function. Therefore, some cases of subclinical hypothyroidism can be treated by reducing iodine intake in areas with excessive iodine intake such as Japan.

Second, various aspects of laboratory medicine need to be taken into account. As Cai et al. describe, TSH concentrations are not identical when measured using the various kit-based assays used in different countries. The development of the TSH immunoassay has made it possible to diagnose subclinical thyroid dysfunction. The second-generation assays (available from 1984) had a functional limit of $0.1 \mathrm{mIU} / \mathrm{L}$, falling very close to the normal lower limit, which was approximately $0.3 \mathrm{mIU} / \mathrm{L} .{ }^{6}$ Hence, their diagnostic accuracy might be low because certain milder degrees of hyperthyroidism could not be detected. With the third-generation assays (available from 1989), however, the sensitivity limit of $0.01 \mathrm{mIU} / \mathrm{L}^{7}$ was so much lower than normal that, although there was still noise around the sensitivity limit, diagnostic information became much more reliable. ${ }^{8}$

At present, the laboratory tests for TSH, FT4 and FT3 designed to analyze thyroid function vary among institutions around the world because commercial kits used for clinical laboratory tests have not yet been internationally standardized. ${ }^{8}$ Several types of commercial kits were used to measure thyroid function in the study by Cai et al. ${ }^{4}$ The standardization of clinical laboratory tests is very important because it facilitates clinical interpretation and allows for comparison of assay results across different studies and clinical laboratories. ${ }^{9}$ However, many biological and methodological challenges complicate the standardization of immunoassays for thyroid function. One of these is the fact that TSH is not a single homogeneous protein; circulating TSH is composed of several different isoforms. ${ }^{9}$

Third, Cai et al. did not have access to information regarding the duration of the 
subclinical state for individual patients in this study. ${ }^{4}$ Because some cases with subclinical hypothyroidism are known to have attained normalized thyroid function spontaneously, and because Biondi et al. ${ }^{10}$ reported that the duration of subclinical hyperthyroidism was associated with an increase in left ventricular volume, the duration of subclinical thyroid dysfunction needs to be verified in future studies.

Finally, Razvi et al. ${ }^{11}$ have recently suggested that L-T4 replacements improve cardiovascular risk factors and endothelial function in subclinical hypothyroidism. However, it is still not clear whether the normalization of subclinical thyroid dysfunction leads to a change in blood pressure.

The study by Cai et al. is obviously an important initial step toward understanding the pathogenesis of increasing blood pressure in a state of subclinical hypothyroidism. It is expected that further prospective randomized studies will clarify the relationship between blood pressure and subclinical thyroid dysfunction.

\section{CONFLICT OF INTEREST}

The author declares no conflict of interest.

1 Hollowell JG, Staehling NW, Flanders WD, Hannon WH, Gunter EW, Spencer CA, Braverman LE. Serum TSH, $\mathrm{T}(4)$, and thyroid antibodies in the United States population(1988 to 1994): National Health and Nutrition Examination Survey (NHANES III). J Clin Endocrinol. Metab 2002; 87: 489-499.

2 Hak AE, Pols HA, Visser TJ, Drexhage HA, Hofman A, Witteman JC. Subclinical hypothyroidism is an independent risk factor for atherosclerosis and Myocardial infarction in elderly women: the Rotterdam Study. Ann Intern Med 2000; 132: 270-278.

3 Fazio S, Palmieri EA, Lombaradi G, Biondi B. Effects of thyroid hormone on the cardiovascular system. Recent Prog Horm Res 2004; 59: 31-50.

4 Cai Y, Ren Y, Shi J. Blood pressure levels in patients with subclinical thyroid dysfunction: a meta-analysis of cross-sectional data. Hypertens Res 2011; 34: 1098-1105.
5 Anderson M, Takkouche B, Egli I, Allen HE, de Benoist B. Current global iodine status and progress over the last decade towards the elimination of iodine deficiency. Bull World Health Organ 2005; 83: 518-525.

6 Report from a joint WHO/UNICEF/ICCIDD consultation. Indications for assessing iodine deficiency disorders and their control programmes. WHO/NUT 1994; 1: 14.

7 Nagataki S. The average of dietary iodine intake due to the ingestion of seaweeds is $1.2 \mathrm{mg} / \mathrm{day}$ in Japan. Thyroid 2008; 18: 667-668.

8 Sgoutas DS, Tuten TE, Verras AA, Love A, Barton EG. Aqualite bioluminescence assay of thyrotropin in serum evaluated. Clin Chem 1995; 41: 1637-1643.

9 Thienpont LM, Uytfanghe V, Beastall G, Faix JD, leiri T, Miller WG, Nelson JC, Ronin C, Ross HA, Thijssen JH, Toussaint B. Report of the IFCC working group for standardization of thyroid function tests; part 1: thyroid-stimulating hormone. Clin Chem 2010; 56: 902-911.

10 Biondi B, Fazio S, Carella C, AMATo G, Cittadini A, Lupoli G, Sacca L, Bellastella A, Lombardi G. Cardiac effects of long term thyrotropin-suppressive therapy with levothyroxine. J Clin Endocrinol Metab 1993; 77: 334-338.

11 Razvi S, Ingoe L, Keeka G, Oates C, McMillan C, Weaver JU. The beneficial effect of L-thyroxine on cardiovascular risk factors, endothelial function, and quality of life in subclinical hypothyroidism: randomized, crossover trial. J Clin Endocrinol Metab 2007; 92: 1715-1723. 